\title{
Vitrification and sinter-crystallization of fly ash with glass cullet
}

\begin{abstract}
The synthesis of a new glass-ceramic obtained by sinter-crystallization has been investigated by using soda-lime-silicate glass waste and fly ashes from a coal power thermal station located in Andorra (Teruel, Spain). An original glass as frit with composition of $50 \mathrm{wt} \%$ recycled soda-lime glass, $25 \mathrm{wt} \%$ bottom ash, $15 \mathrm{wt} \%$ fly ash and $10 \mathrm{wt} \% \mathrm{CaCO}$ has been melted. After sinter-crystallization at $850^{\circ} \mathrm{C}$, it has precipitated two main crystalline phases: sodium anorthite and the hedenbergite. The linear shrinkage is $1 / 3$ of the value of conventional porcelainized stoneware and the water absorption of this glass-ceramic is similar to a conventional porcelainized stoneware tile (less than $1 \mathrm{wt} \%$ ), being the apparent density slightly higher than this type of tiles $\left(2.6 \mathrm{~g} / \mathrm{cm}^{3}\right.$ instead of $\left.2.4 \mathrm{~g} / \mathrm{cm}^{3}\right)$. Flexural strength is near twice than porcelainized stoneware (around $950 \mathrm{~kg} / \mathrm{cm}^{2}$ instead of $550 \mathrm{~kg}$ / $\left.\mathrm{cm}^{2}\right)(95 \mathrm{MPa}$ in the new glass- ceramic with respect to 55MPa for the above mentioned as reference material).
\end{abstract}

Keywords: recycling, industrial wastes, glass-ceramics, sinter-crystallization; fly ashes
Volume 3 Issue 5 - 2019

\author{
Stoyanova Lyubenova T, Fraga D, Barrachina \\ E, Calvet I, Carda JB \\ Department of Inorganic and Organic Chemistry, Universitat \\ Jaume I, Castellón, Spain
}

Correspondence: Barrachina E, Department of Inorganic and Organic Chemistry, Universitat Jaume I, Castellón, Spain, Email ebarrach@uji.es

Received: September 25, 2019 | Published: October 31, 2019
Abbreviations: XRF, X-ray fluorescence; TTT, timetemperature-transformation diagram; EDS, energy dispersive X-ray spectrometer; SEM, scanning electron microscopy

\section{Introduction}

Nowadays, in this second decade of this century, the industrial residues they continue generating environmental problems. Such of these wastes (glass cullet and bottom or fly ashes from the coal power stations) are still abundant and not definitive applications or solutions for its immobilizing have been given, though a considerable amount of research has been conducted in the last years. One of the promising applications proposed by laboratories research has been their potential for being used in the construction industry. ${ }^{1,2}$ With respect the glass cullet from the conventional glass there is abundant research carried out in the last decades of 20th and beginning of this 21 st century. ${ }^{3-5}$ Vitrification process has been demonstrated is an adequate processing method for inertize toxic and abundant residues and even to facilitate their recycling as secondary raw materials in ceramics and glasses industries. ${ }^{6}$ Transforming of starting glasses after vitrification into glass-ceramics by controlled thermal treatment is possible to reach immobilizing of a wide range of industrial wastes (mineral residues, sludges from dumps, slags, ashes,). Besides, the low cost and great availability of waste make these glass-ceramics materials very attractive from an economical and technological point of view, so synthetic high-performance materials with broad applications in construction and civil engineering can be obtained from residues. ${ }^{7}$ Therefore, it has been the aim of this research to explore the synthesis of a new type of glass-ceramic by the sinter-crystallization process from soda-lime-silicate glass and several ashes from a coal power thermal station located in Andorra (Teruel, Spain).

\section{Materials and methods}

The batch original composition for melting of an "mother or original" glass able for being transformed in a glass-ceramic was: $25 \mathrm{wt} \%$ bottom ash (from Andorra), $15 \mathrm{wt} \%$ fly ash (from Andorra), $10 \mathrm{wt} \%$ calcium carbonate (industrial $\mathrm{CaCO}_{3}$ ) and $50 \mathrm{wt} \%$ of glass cullet (from the recycling glass sector). The chemical composition determined by XRF analysis of wastes and raw materials is shown in Table 1. X-ray fluorescence (XRF) dispersion wavelength equipment was the model S4 Pioneer - Bruker. The same Table 1 includes the XRF analysis of the final glass-ceramic. This mixture has been melted at $1500^{\circ} \mathrm{C}$ during 1 hour in a lift furnace by using a refractory crucible and then, the glass composition has been quenched in cold water to obtain glassy granules, ready to be wetly milled in an alumina ball mill under $45 \mu \mathrm{m}$. The dried glassy powder $(24 \mathrm{~h}$ at $110^{\circ} \mathrm{C}$ ) has been moistened at about $10 \mathrm{wt} \%$ to be pressed with a Nannetti ${ }^{\circledR}$ uniaxial press up to a pressure of $30 \mathrm{MPa}$ in the shape of rectangular glassy pieces. The pieces were subjected to the thermal firing cycle in a muffle kiln (Nannetti $\left.{ }^{\circledR}\right)$, which has been achieved by varying the maximum temperature $\left(700^{\circ} \mathrm{C}-1000^{\circ} \mathrm{C}\right)$ and the residence period $(30 \mathrm{~min} / 10 \mathrm{~h})$ in order to elaborate the corresponding TimeTemperature-Transformation diagram (TTT). The different heat treated samples at successive temperatures and time for drawing the TTT diagram was characterized by XRD and SEM/EDS. Crystalline phases were identified X-ray diffraction (XRD) and by using a BrukerAXS D4 Endeavor equipment (using Ni-filtered $\mathrm{Cu}-\mathrm{K} \alpha$ radiation with scanning speed of $2^{\circ}(2 \square)$ per minute and registering the diffraction pattern in the $10^{\circ}-80^{\circ}$ Bragg angle range. The microstructure was observed by scanning electron microscopy (SEM) JEOL 7001F with energy dispersive X-ray spectrometer (EDS) operating in the $15-20 \mathrm{kV}$ interval. 
Table I Semiquantitative analysis (XRF) of industrial wastes and the glass-ceramic

\begin{tabular}{|c|c|c|c|c|c|c|c|c|c|c|}
\hline$w t \%$ & $\mathrm{Na}_{2} \mathrm{O}$ & $\mathrm{MgO}$ & $\mathrm{Al}_{2} \mathrm{O}_{3}$ & $\mathrm{SiO}_{2}$ & $\mathbf{P}_{2} \mathbf{O}_{5}$ & $\mathbf{K}_{2} \mathbf{O}$ & $\mathrm{CaO}$ & $\mathrm{TiO}_{2}$ & $\mathrm{Fe}_{2} \mathrm{O}_{3}$ & LOI* \\
\hline \multicolumn{11}{|c|}{ Wastes } \\
\hline Glass & 12,59 & 3,75 & 0,85 & 73,16 & 0,01 & 0,30 & 8,94 & 0,05 & 0,10 & 0.10 \\
\hline Slag & - & 1,13 & 23,85 & 43,19 & 0,31 & 1,13 & 5,22 & 0,72 & 23,85 & 0,20 \\
\hline Fly ash & 0,20 & 1,23 & 26,63 & 44,44 & 0,41 & $\mathrm{I}, 23$ & 5,53 & 0,92 & 18,43 & 0,15 \\
\hline $\mathrm{CaCO}_{3}$ & - & - & - & - & - & - & 55,98 & - & - & 44,01 \\
\hline \multicolumn{11}{|c|}{ Glass-ceramic } \\
\hline Glass- ceramic & 6,83 & 2,10 & 17,05 & 52,75 & - & 0,78 & 12,34 & 0,36 & 7,69 & 0,03 \\
\hline
\end{tabular}

\section{*LOI, loss on ignition}

The physical and technological properties, such as apparent density (hydrostatic balance method), flexural strength (determined by a HOYTOM ${ }^{\circledR}$ plasticinometer under load cell of $5000 \mathrm{~N}$ and $16 \mathrm{~N}$ initial force), linear shrinkage (Mitutoyo ${ }^{\circledR}$ digital caliper) were determined in the original glass and glass-ceramics. Linear shrinkage was determined, as is usual by considering the initial length (Li), the length of the dried piece and the final length (Lf) of the heat treated sample: $\% \mathrm{Sh}=(\mathrm{Li}-\mathrm{Lf}) / \mathrm{Li} \bullet 100$. Water absorption has been determined according to the Quality Normative for Ceramic Tiles (UNE-EN-ISO 10545-3).

\section{Results}

\section{Chemical composition}

The final composition of original glass and corresponding glassceramic was: $\mathrm{SiO}_{2}(52.75 \mathrm{wt} \%), \mathrm{Al} 2 \mathrm{O} 3(17.05 \mathrm{wt} \%), \mathrm{CaO}(12.34 \mathrm{wt} \%)$, $\mathrm{Fe}_{2} \mathrm{O}_{3}(7.69 \mathrm{wt} \%)$ and $\mathrm{Na}_{2} \mathrm{O}(6.83 \mathrm{wt} \%)$.

\section{Experimental diagram (TTT diagram)}

The experimental TTT diagram which has been represented in the Figure1 shows the "nose curve" dividing the three main zones: a) the amorphous area outside the curve, where the glass stay vitreous without depicting diffraction peaks; b) the zone inside the nose curve where the crystallites nucleate and growth and c) the superior outside nose curve, where takes place the softening of glass and melting. Besides, X-ray diffractograms corresponding to samples fired for 30min are displayed in Figure1B.

\section{Microstructural morphology}

The microstructural morphology of heat treated samples during 30 minutes has been observed by SEM (Figure 2).


Figure I A) TTT Diagram of the composition. B) X-ray diffractograms from samples treated during 30 minutes at successive temperatures from 800 to $1000^{\circ} \mathrm{C}$. 

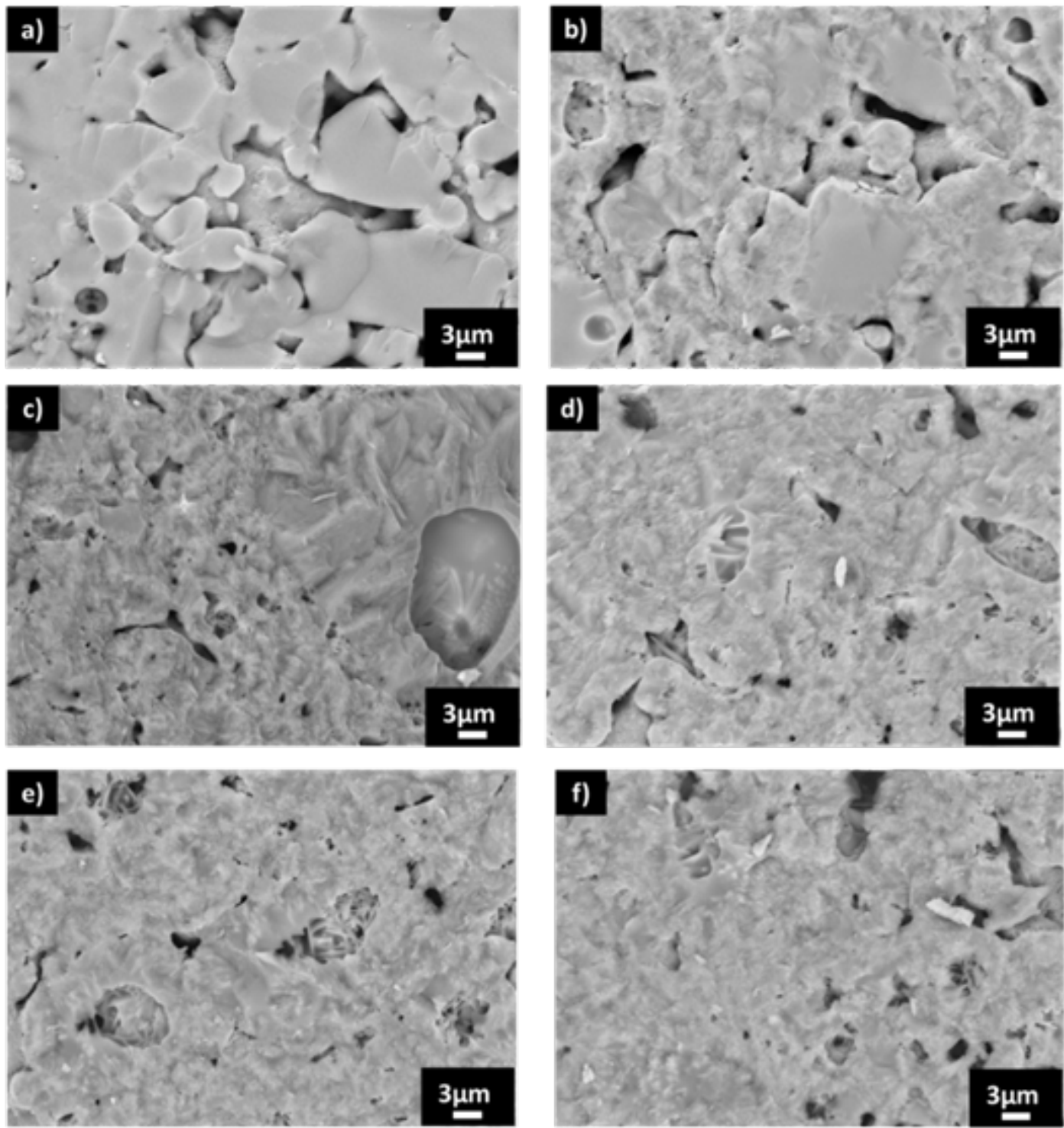

Figure 2 Microstructure observed by SEM from different samples heat treated during 30 minutes at A) $\left.\left.\left.\left.800^{\circ} \mathrm{C}, \mathrm{B}\right) 850^{\circ} \mathrm{C}, \mathrm{C}\right) 900^{\circ} \mathrm{C}, \mathrm{D}\right) 950^{\circ} \mathrm{C}, \mathrm{E}\right) 975^{\circ} \mathrm{C}, \mathrm{F}$ ) $1000^{\circ} \mathrm{C}$.

\section{Ceramic properties}

The variations on apparent density and flexural strength vs temperature are displayed in Figure 3a, while the linear shrinkage and water absorption vs temperature are plotted in Figure 3B. These parameters are essentials to control the quality of the final product, because it has a ceramic application, being susceptible to cover floors and walls.

\section{Discussion}

About the chemical composition, it is expected the devitrification of crystalline phases belonging to the more common simplified $\mathrm{CaO}$ $\mathrm{Al}_{2} \mathrm{O}_{3}-\mathrm{SiO}_{2}$ ternary system, in which the fly ashes are usually located and mineral substitutions due to transition element oxides. ${ }^{1}$ Referring to the TTT diagram, the crystallization occurs from $850^{\circ} \mathrm{C}$ and is independent of time of heat treatment (Figure 1A). Besides, $850^{\circ} \mathrm{C}$ is a relatively low temperature that together with the short time of operation, become an economically profitable industrial process. The $\mathrm{X}$-ray diffractograms of samples treated at $800-1000^{\circ} \mathrm{C}$ during 30 minutes of residence time are shown in Figure 1B. The sample tested at $800^{\circ} \mathrm{C}$ is completely amorphous, whereas the samples subjected to temperatures from $850^{\circ} \mathrm{C}$ to $950^{\circ} \mathrm{C}$ show the most intense peaks of the solid solution of sodium anorthite (JCPDS card No. 86-1650), a mineral phase of anorthite where some $\mathrm{CaO}$ has been substituted by $\mathrm{Na}_{2} \mathrm{O}$, which is present in the glass-ceramic (Table 1) in an approximate content of $7 \mathrm{wt} \%$ and hedenbergite (JCPDS card No. 70-1876), a diopside-pyroxenic phase with iron substitutions. While this sodium-anorthite presents its maximum intensity at $900^{\circ} \mathrm{C}$, the hedenbergite shows the maximum crystallinity at $950^{\circ} \mathrm{C}$. Both phases exhibit competitive mechanical properties. 
About microstructural morphology, at $800^{\circ} \mathrm{C}$, the corresponding SEM micrograph shows the presence of glassy particles partly sintered and without signs of crystallization, while at $850^{\circ} \mathrm{C}$ the vitreous particles show heterogeneities of crystals nuclei. Since $900^{\circ} \mathrm{C}$ to $1000^{\circ} \mathrm{C}$ micrographs exhibit the presence of crystals inside the sintered particles. The average chemical analysis by EDX of the crystals in these crystallized samples shows the following oxides: 6.0 wt $\% \mathrm{Na}_{2} \mathrm{O}, 0.9$ wt $\% \mathrm{MgO}, 15.5 \mathrm{wt} \% \mathrm{Al}_{2} \mathrm{O}_{3}, 61.2 \mathrm{wt} \% \mathrm{SiO}_{2}, 0.8 \mathrm{wt} \%$ $\mathrm{K} 2 \mathrm{O}, 8.8 \mathrm{wt} \%, \mathrm{CaO}, 6.7 \mathrm{wt} \% \mathrm{Fe}_{2} \mathrm{O}_{3}$, showing that there is a mixture of both phases, the sodium anorthite, and the hedenbergite. Figure $3 \mathrm{~A}$ shows density values with a maximum value $\left(2.60 \mathrm{~g} / \mathrm{cm}^{3}\right)$ is reached $850^{\circ} \mathrm{C}$, been more or less constant until $1000^{\circ} \mathrm{C}$, in samples heat treated at 30 minutes. This value is higher and is obtained at lower temperatures than in the case of porcelain ceramic tiles, which reaches an only apparent bulk density of $2.40 \mathrm{~g} / \mathrm{cm}^{3}$ at $1200^{\circ} \mathrm{C}$. The flexural strength increases with temperature, achieving the maximum (around $95 \mathrm{MPa}$ ) at $950^{\circ} \mathrm{C}$ when the hedenbergite shows the higher value. At higher thermal treatment temperature $\left(1200^{\circ} \mathrm{C}\right)$, the resulting tile shows a conventional value of $60 \mathrm{MPa}$. The linear shrinkage (Figure 3B) shows the same behavior than the apparent density and reaching the maximum (around $2.5 \%$ ) at $850^{\circ} \mathrm{C}$, remaining almost constant until $1000^{\circ} \mathrm{C}$. In contrast, the water absorption (Figure 3B) exhibits a large reduction at $850^{\circ} \mathrm{C}$, where the maximum linear shrinkage is obtained, holding at similar values of $1 \%$ until $975^{\circ} \mathrm{C}$. After $975^{\circ} \mathrm{C}$ continues its reduction from $1 \%$ to $0.5 \%$, because the vitreous phase is growing whilst crystals are dissolving, a phenomenon which gives rise to the porous sealing, as can be seen in the SEM micrographs (Figure 2F). Compared to a conventional porcelainized stoneware tile, this glassceramic material exhibits a much lower shrinkage $(2.5 \%$ with respect the $7.5 \%$ of porcelain tile) and similar water absorption at maximum apparent density (in both materials less 1\%). Therefore, a conclusion it is evident the advantages of using glass cullet for obtaining a new type of glass-ceramic tiles.
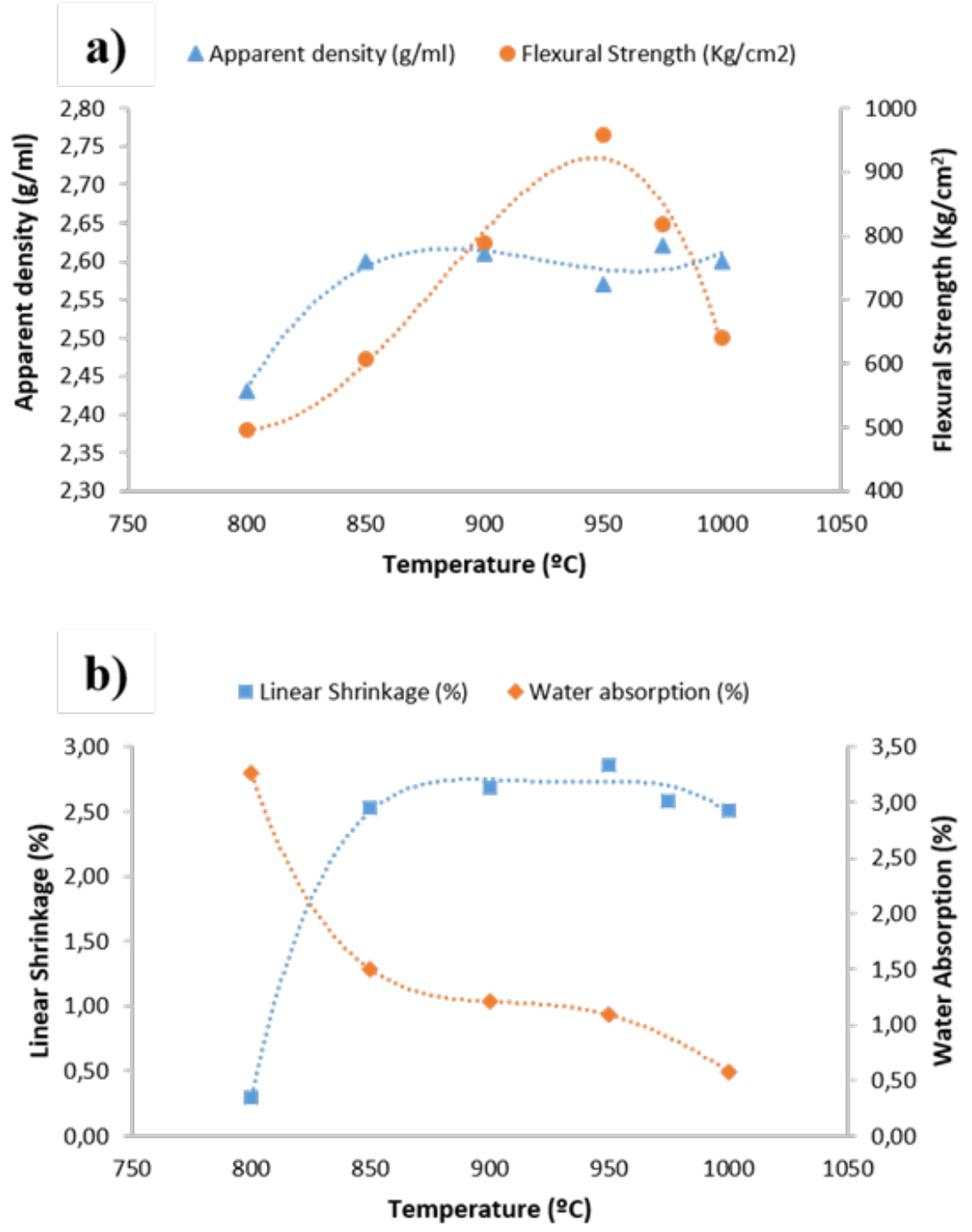

Figure 3 Variation of the glass-ceramic technological properties heat treated during 30 minutes:A) apparent density and flexural strength vs temperature and B) linear shrinkage and water absorption vs temperature. 


\section{Conclusion}

It has been obtained a high-resistance glass-ceramic tile formulated from industrial residues ( $50 \%$ glass cullet, $25 \%$ bottom ash, $15 \%$ fly ash and $10 \% \mathrm{CaCO}^{3}$ ), which exhibits better technological properties $\left(2.60 \mathrm{~g} / \mathrm{c}^{\mathrm{m} 3}\right.$ apparent density and $95 \mathrm{MPa}$ flexural strength) than conventional porcelainized stoneware tiles.

\section{Funding}

This research was funded by the Spanish Government through the National Research Programs: RETO INVESTIGACIÓN "SUNBEAM" (ENE2013-49136-C4-2-R) and RETO COLABORACIÓN “ECOART” (RTC-2014-2294-3).

\section{Acknowledgments}

The authors thank J. Ma. Rincón for reviewing and correcting this manuscript.

\section{Conflicts of interest}

The authors declare no conflict of interest.

\section{References}

1. Romero M, Jesus Maria Rincón. Use of thermoelectric power plant fly ash in the production of low-cost glasses and glass- ceramics, Ceramica Informazione. 1997;371:282-285.

2. Romero M, Jesus Maria Rincón. New glasses and glass-ceramics by recycling of Spanish urban incinerator fly ashes. Key Engineering Materials. 2002:883-886.

3. Silva RV, De Brito J, Lye CQ, et al. The role of glass waste in the production of ceramic-based products and other applications: A review. $J$ Clean Prod. 2017;167:346-364.

4. Mohajerani A, Vajna J, Cheung THH, et al. Practical recycling applications of crushed waste glass in construction materials: A review. Constr Build Mater. 2017;156:443-467.

5. Ponsot I, Bernardo E, Bontempi E, et al. Recycling municipal waste incinerator fly ash and soda-lime glass into sintered glass-ceramics. $J$ Clean Prod. 2015;89:224-230.

6. J Rincón Ma. Vitreous and ceramic processing for the recycling of industrial wastes. Key Engineering Materials. 2016;663:11-22.

7. Romero M Rincón J. Glass-ceramics as building materials, Mater. Construct. 1996;46:242-243. 